\title{
Yield Impact and Spread of Pineapple mealybug wilt associated virus-2 and Mealybug Wilt of Pineapple in Hawaii
}

\author{
D. M. Sether and J. S. Hu, University of Hawaii at Manoa, Department of Plant and Environmental Protection Sci- \\ ences, Honolulu 96822
}

\section{ABSTRACT}

Sether, D. M., and Hu, J. S. 2002. Yield impact and spread of Pineapple mealybug wilt associated virus-2 and mealybug wilt of pineapple in Hawaii. Plant Dis. 86:867-874.

The impact of mealybug feeding and Pineapple mealybug wilt associated virus-1 (PMWaV-1) and PMWaV-2 infection on pineapple fruit yield, and the spread of PMWaV-1 and mealybug wilt of pineapple (MWP) were evaluated under field conditions with a randomized complete block design. Plots of PMWaV-1-free or infected plants were maintained mealybug-free or inoculated with mealybugs (Dysmicoccus spp.) at monthly intervals. Plants infected with PMWaV-2, an integral part of MWP etiology, were nested within plots that were maintained free of mealybugs, and in the plots of PMWaV-1 infected plants exposed to mealybugs. MWP, which only developed in PMWaV-2 infected plants exposed to mealybugs, resulted in a $35 \%$ reduction in yield when compared to PMWaV-free plants. Yield reductions were dependent on time of MWP symptom development; the earlier the expression of symptoms the greater the impact on fruit yields. An interaction effect between PMWaV infection, inclusive of both PMWaV-1 and PMWaV-2 infected plants, and mealybug exposure was detected in the plant crop $(P<0.02)$ but not in the ratoon crop $(P>0.59)$. This could be explained by the presence of MWP symptom expression during the plant crop and subsequent plant recovery in the ratoon crop. Virus infection, inclusive of PMWaV-1 and PMWaV-2, suppressed yield $(P<0.01)$ in the ratoon crop. The commercially desirable fruit sizes were most frequently obtained from PMWaV-free plants. Spatial analysis of PMWaV-2 spread, and MWP symptom expression in mealybug inoculated plots showed patterns of aggregation within rows and within beds but not between beds over the course of the study. Initial occurrence of MWP symptom expression in mealybug-inoculated plots was underdispersed indicating random occurrence of PMWaV-2 plants. After 6 months of mealybug exposure, patterns of both PMWaV-2 incidence and MWP were overdispersed. Management strategies are discussed.

Additional keywords: closterovirus, vector transmission

Mealybug wilt of pineapple (MWP) is a devastating disease found in all the major pineapple growing regions of the world (4$6,26)$. The disease is characterized by severe tip dieback, downward curving of the leaf margins, reddening, and wilting of the leaves that can cause total collapse of the plant. The etiology of MWP has long been in question. The disorder is generally associated with the presence of mealybugs $(3,6,20)$, however, not every mealybuginfested plant develops MWP (7,8,16,28, 29,31). Hypotheses have suggested the involvement of a latent transmissible factor such as a virus $(8,15)$, and long flexuousrod shaped particles were isolated from MWP symptomatic plants (14). Subsequently, closterovirus particles were detected in both MWP symptomatic and asymptomatic pineapple worldwide $(1,17$, $18,27,28,31,32,34)$.

Corresponding author: D. M. Sether

E-mail: sether@hawaii.edu

Accepted for publication 29 March 2002.

Publication no. D-2002-0528-02R

(C) 2002 The American Phytopathological Society
The particles, referred to as Pineapple mealybug wilt associated virus (PMWaV), are actually a complex of at least two different viruses $(18,25,31,32)$. Both viruses are mealybug transmitted $(31,33)$ and are in the Closteroviridae family $(22,25)$. Based on sequence and phylogenetic analyses, PMWaV-1 and PMWaV-2 share approximately 50\% homology (M. J. Melzer, A. Karasev, D. M. Sether, and J. S. $\mathrm{Hu}$, unpublished). PMWaV-2 is most closely related to Grapevine leafroll associated virus 3 (GLRaV-3) sharing 69.4, $71.5,70.1$, and $63.9 \%$ sequence similarity for the helicase, RNA-dependent RNApolymerase, heat shock protein 70 homolog, and coat protein genes, respectively (25). Two monoclonal antibodies (MAbs), 35-6-5 (PMWaV-1) (18) and 63-2-2 (PMWaV-2) (31) can detect and differentiate the two viruses in tissue blot immunoassays (TBIAs) (17). TBIAs with PMWaV1 and PMWaV-2- specific MAbs and reverse transcription polymerase chain reaction (RT-PCR) assays have shown that both viruses are found worldwide in MWP symptomatic and asymptomatic pineapple $(17,32)$. However, PMWaV-2 infection is consistently found in association with MWP (31), whereas PMWaV-1 is not (17).
In healthy appearing Hawaiian grown proprietary selections of Ananas comosus cv. Smooth Cayenne, PMWaV-1 occurs at a much higher incidence (26 to $100 \%$ ) than dual infections of PMWaV-1 and PMWaV2 (0 to $36 \%)$ (32). In all but one of the proprietary pineapple selections from Hawaii, single infections of PMWaV-2 occur with the least frequency (0 to 8\%) (32). In recent studies, we have shown that both mealybug exposure and PMWaV-2 play a role in MWP etiology (29,31). Mealybug feeding in the absence of PMWaV-2 or PMWaV-2-infection in the absence of mealybug feeding does not result in MWP (31).

An experiment using a randomized complete block design consisting of PMWaV-1-free and PMWaV-1-infected pineapple plants either maintained mealybug-free or inoculated with mealybugs at regular intervals was established in a commercial pineapple field on Maui, Hawaii. During the course of this study, we identified and characterized PMWaV-2 (25). This virus was identified in plants that were distributed throughout the treatment plots. RT-PCR assays that could detect and differentiate PMWaV-1 and PMWaV-2 (32) and PMWaV-2-specific TBIAs (31) were used to monitor the spatial patterns of PMWaV-2 infections and MWP over time. Yield impacts of the two PMWaVs, mealybug exposure, and MWP are also presented, and management strategies are discussed.

\section{MATERIALS AND METHODS}

Experimental design. Pineapple is a perennial monocot that is propagated by crowns from the top of the fruit or from suckers (23). In Hawaii, crowns are planted through plastic mulch and grown for 18 to 20 months before fruit harvest. This is referred to as the plant crop. After plant crop fruit harvest each plant typically gives rise to one or more ratoons before drying up. Fruit from this ratoon crop will be harvested 12 to 15 months after the plant crop was harvested. PMWaV-1specific TBIA, as previously described (17), was used to identify the virus status of each crown used for planting the plant crop. The initial PMWaV-2 infection status of the crowns was not determined because of unavailability of an assay appropriate for mass screening at the beginning of the study. The area was prepared using standard plantation practices. Soil was fumigated with methyl bromide, drip irrigation lines were installed down the middle of 
each bed, and beds were covered with black plastic mulch. Treatments of PMWaV-1-free or PMWaV-1-infected plants either maintained mealybug-free or inoculated with mealybugs were arranged factorially and replicated four times. Each treatment plot consisted of 130 crowns planted through the plastic on $28 \mathrm{~cm}$ centers in two beds, each with two rows. Rows within a bed were $40 \mathrm{~cm}$ apart. Beds were separated by a 70 -cm-wide aisle. The 16 treatment plots were separated from one another by a minimum of two beds of PMWaV-1-free plants on two sides and 7.7 $\mathrm{m}$ plantings of $\mathrm{PMWaV}-1$-free plants on the ends. Plots consisted of pineapple crowns with or without PMWaV-1 and the presence or absence of mealybugs. Plots that were maintained mealybug-free received applications of Prentox diazinon $50 \mathrm{~W}$ at $4 \mathrm{lb} / \mathrm{acre}$. Amdro ant bait (American Cyanamid Co. Parsippany, NJ) was applied as a broadcast treatment twice during the course of the study to prevent ants from becoming established. Mealybugs (Dysmicoccus brevipes (Cockerell) and D. neobrevipes Beardsley) reared on squash were applied to mealybug-exposed treatments at monthly intervals during the plant crop as previously described $(31,33)$. Each application consisted of approximately 10,000 mealybugs of both species per plot beginning 45 days after planting. Mealybug applications were suspended 3 months before harvest of the plant crop.

Data collection. Presence or absence of MWP symptoms and plant location within treatment plots were noted for each plant at monthly intervals beginning 2 months after planting and continuing throughout the plant crop cycle. Four months after planting, RT-PCR assays for PMWaV-2 were developed (32). This assay was used to screen the plants in the treatment plots for PMWaV-2 infection at monthly intervals beginning 4 months after planting. PMWaV-2-infected plants were removed from the mealybug-treated plots of PMWaV-1-free plants to assure evaluation of mealybug feeding impact in the absence of MWP. PMWaV-2-infected plants were left in place in the other 12 plots, and the pattern of virus spread in mealybuginoculated plots was recorded at monthly intervals. Duplicate sets of leaf blots for TBIA analyses were made from all plants at 6, 10, and 14 months after planting and at the time of plant and ratoon crop harvests. After PMWaV-2-specific MAb 63-22 was produced (31), the blots were screened with PMWaV-1- and PMWaV-2specific MAbs in parallel TBIAs (17). Fruit produced in the plant and ratoon crops were individually weighed with and without the crown. A leaf sample was removed from the crown and tested for PMWaV-1 and PMWaV-2 in virus-specific TBIA at the time of harvest to confirm virus status.

Statistical analyses. Fruit with crowns were separated into commercial fresh fruit size classes as follows: size 7 (2.6 to 2.9 $\mathrm{kg}$ ); size 8 (2.1 to $2.5 \mathrm{~kg}$ ); size 10 (1.7 to $2.0 \mathrm{~kg}$ ); size 12 (1.4 to $1.6 \mathrm{~kg}$ ); size 14 (1.2 to $1.3 \mathrm{~kg})$; size 16 (1.0 to $1.1 \mathrm{~kg})$; Under $(<1.0 \mathrm{~kg}$ ); and Over (over $3.0 \mathrm{~kg}$ ). Sizeclass frequency distributions were generated for fruit weights from the plant and ratoon crops. Size frequencies were expressed as a percentage of the total number of fruit produced per treatment for each size category. Mann Whitney tests at $\alpha=$ 0.05 (9) were used to compare size class percentages from the replicate plots between treatments. The average fruit weights in the treatment plots, inclusive of PMWaV-1 and dually infected plants for PMWaV-1-infected treatments, were analyzed with analysis of variance (ANOVA), and Fisher's LSD means separation procedure was used where appropriate (SAS Institute, Cary, NC). Because PMWaV-2 was discovered in the treatment plots when detection assays became available, PMWaV-2 infection was treated as a subtreatment and individual fruit weights were analyzed with nested ANOVA, and means separation procedures were used where appropriate (SAS Institute). The time of MWP symptom appearance, expressed as months after planting, and yield were analyzed with power regression analysis.

Spatial analysis. The patterns of MWP symptomatic plants and PMWaV infection within plots were analyzed with ordinary runs analysis (2). A run was defined as a succession of one or more plants of one type of status (symptomatic versus asymptomatic or PMWaV-2-free versus PMWaV-2 infected) preceded or followed by the opposite plant status in a row (24). The expected number of runs

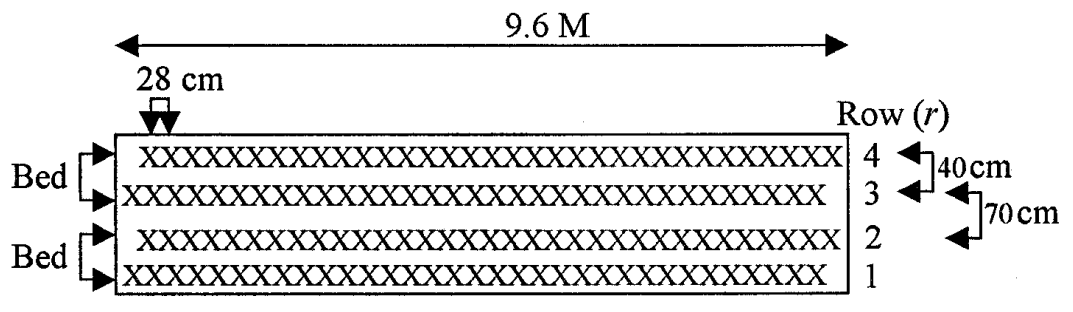

Plot

Fig. 1. Planting layout of pineapple plants within a treatment plot. under the null hypothesis of randomness is given by

$$
E(U)=1+\frac{2 m(N-m)}{1}
$$

where $E(U)$ is the expected number of runs, $m$ is the number of symptomatic or PMWaV-2-infected plants in the row, and $N$ is the total number of plants in the row (24). If clustering is present, the number of runs $(U)$ will be less than $E(U)(11)$. The standard deviation of $U$ given the hypothesis of underdispersion is given by

$$
S(U)=\left(\frac{2 m(N-m)(2 m N-m)-N}{N^{2}(n-1)}\right)^{\frac{1}{2}}
$$

and the normal test to determine clustering is given by

$$
Z=\frac{(U+0.5-E(U)}{s(U)}
$$

which includes a continuity correction coefficient (11).

For down-the-row analysis, the four rows that composed each plot were combined end for end so that the last plant of row $r$ was contiguous with the first plant of row $r+1$ (Fig. 1). An achieved significance level $(P)$ was calculated for each plot (11). Pineapple planting patterns present a problem for across-row analyses because plants are planted in a nonlattice arrangement. Rather, plants in adjacent rows are offset from one another (Fig. 1). To adapt to the offset placement of plants in adjacent rows, across-rows and across-beds analyses were modified as follows. Adjacent rows were analyzed in pairs and linearized as if they formed one contiguous row (Fig. 1.). For example, plant $X$ in row 1 was followed by plant $X$ in row 2, followed by plant $X+1$ in row 1 , followed by plant $X+1$ in row 2 and continuing to alternate between the two adjacent rows through the last plant of the two rows. Three "paired row" significance levels $(P)$ were calculated per plot; two representing rows within the same bed and one representing the two middle rows of the plot that were in different beds. All $P$ values for linearized rows 1 and 2 and 3 and 4 were grouped together because they represented paired rows within the same bed and all linearized rows 2 and 3 were grouped together because these were adjacent rows in different beds. These two groups of $P$ values were subjected to an overall test for randomness given by

$$
V=-2 \sum_{i}^{n} \ln \left(P_{i}\right)
$$

where $n=$ the number of paired rows, $i$ represents the $i$ th linearized row. $V$ has a chi-square distribution with $2 n$ degrees of freedom (2).

\section{RESULTS}

Incidence of PMWaV-2 in plots of PMWaV-1-free plants varied from less 
than 1 to $4 \%, 4$ months after planting. These plants were left in place in plots that were not treated with mealybugs, but were removed from $\mathrm{PMWaV-1-free} \mathrm{plots} \mathrm{that}$ were treated with mealybugs to prevent secondary spread of PMWaV-2. The number of plants removed from the four replicate plots of mealybug-inoculated, PMWaV-1-free plants were 3, 4, 6, and 7 representing 2 to $5 \%$ of the total number of plants in a plot. Three months after mealybug applications began, the incidence of PMWaV-2-infected plants in plots of PMWaV-1-infected plants exposed to mealybugs varied from 21 to $39 \%$ among replicates. In these plots, PMWaV-2 incidence increased over the duration of the plant crop cycle indicating that secondary spread of PMWaV-2 was occurring within this treatment group.

Typical MWP symptoms characterized by severe tip dieback, leaf reddening, downward curling along the leaf margins, and wilting of symptomatic leaves developed in many plants in the four plots of PMWaV-1-infected plants that were exposed to mealybugs. PMWaV-specific RTPCR assays performed on the symptomatic plants showed that these plants were infected with PMWaV-2 in addition to PMWaV-1. A recovery phenotype was observed in most of the MWP symptomatic plants that were characterized by lack of symptoms on the newly formed leaves. Recovery generally occurred 2 to 4 months after MWP symptoms appeared. All plants exhibited a healthy phenotype in the ratoon cycle although plants remained infected with PMWaVs. Mealybug applications were suspended 3 months before plant crop harvest.

An interaction between PMWaVinfection and mealybugs was detected in the plant crop $(P<0.02)$ but not in the ratoon crop $(P>0.59)$ (Table 1). Infection with PMWaV reduced yield in the ratoon

Table 1. Two factor analysis of variance of pineapple fruit yield for the plant and ratoon crops in the presence or absence of Pineapple mealybug wilt associated virus and mealybugs

\begin{tabular}{lrrrrrrrr}
\hline & \multicolumn{3}{c}{ Plant crop } & & \multicolumn{3}{c}{ Ratoon crop } \\
\cline { 2 - 3 } \cline { 7 - 8 } Source & MSE & $\boldsymbol{F}$ Value & \multicolumn{1}{c}{$\boldsymbol{P}$} & & MSE & $\boldsymbol{F}$ Value & \multicolumn{1}{c}{$\boldsymbol{P}$} \\
\hline Block & 5,877 & 3.08 & 0.0828 & & 9,740 & 1.66 & 0.4654 \\
Virus $^{\mathrm{z}}$ & 127,806 & 67.08 & $<0.0001$ & & 109,561 & 10.45 & 0.0103 \\
Mealybug & 12,656 & 6.64 & 0.0298 & & 1,190 & 0.11 & 0.7438 \\
Virus $^{\mathrm{z} * \text { mealybug }}$ & 13,806 & 7.25 & 0.0247 & & 3,136 & 0.30 & 0.5977 \\
\hline
\end{tabular}

${ }^{\mathrm{z}}$ Includes all PMWaV-1-infected plants and plants dually infected with PMWaV-1 and PMWaV-2.

Table 2. Average weight (g) of fruit and crowns produced in the plant and ratoon crops across mealybug and Pineapple mealybug wilt associated virus (PMWaV) treatments

\begin{tabular}{|c|c|c|c|c|}
\hline \multirow[b]{2}{*}{ Treatment } & \multicolumn{2}{|c|}{ Plant crop ${ }^{\mathrm{z}}$} & \multicolumn{2}{|c|}{ Ratoon crop ${ }^{z}$} \\
\hline & Fruit & Crown & Fruit & Crown \\
\hline PMWaV-free & $1,479 \mathrm{a}$ & $154 \mathrm{a}$ & $1,646 \mathrm{a}$ & $242 \mathrm{a}$ \\
\hline PMWaV-1 and -2 infected & $1,300 \mathrm{~b}$ & $156 \mathrm{a}$ & $1,480 \mathrm{~b}$ & $254 \mathrm{a}$ \\
\hline Mealybugs absent & $1,418 \mathrm{a}$ & $155 \mathrm{a}$ & $1,572 \mathrm{a}$ & $251 \mathrm{a}$ \\
\hline Mealybugs present & $1,362 \mathrm{a}$ & $155 \mathrm{a}$ & $1,554 \mathrm{a}$ & $244 \mathrm{a}$ \\
\hline
\end{tabular}

${ }^{\mathrm{z}}$ Means within a column followed by different letters are different $(P<0.05)$ based on Fisher's LSD tests. crop $(P<0.01)$. Across mealybug treatments, PMWaV infection correlated with a 12 and $10 \%$ reduction $(P<0.05)$ in average pineapple fruit weight in the plant and ratoon crops, respectively, (Table 2). Across PMWaV treatments including dually infected plants, mealybug presence correlated with a less than $4 \%$ reduction $(P$ $>0.05)$ of average fruit weight in the cropping cycle (Table 2). Crown sizes from the plant crop and ratoon fruit were not affected by either treatment (Table 2). Evaluation of the main treatments, mealybug presence versus absence and PMWaV presence versus absence simultaneously, showed that the average fruit weight was reduced $(P<0.05)$ when plants were infected by PMWaV and further reduced $(P$ $<0.05$ ) when PMWaVs and mealybugs were present together in the plant crop (treatment groups marked with an asterisk in Table 3). Comparison of these same four groups in the ratoon cycle, showed decreased average fruit weight $(P<0.05)$ in the treatments with mealybugs and viruses together, although MWP symptoms were not present (Table 3). Mealybug applications were not continued into the ratoon crop, but low residual populations of mealybugs were found in all mealybug-treated plots during the ratoon cycle. Based on visual observations, mealybug numbers were generally less than 20 per plant and not every plant appeared infested with mealybugs.

The yield impact described in the previous paragraphs summarized the overall treatment effects of plots of PMWaV-1free, or PMWaV-1-infected, including dually infected plants that were either exposed or not exposed to mealybug feeding. However, the presence of PMWaV-2 within the plots and its correlation with MWP make analyzing subgroups within the treatment groups necessary to further elucidate the causes of the yield reductions that were observed. For this we used individual fruit weights rather than plot means

Table 3. Average pineapple fruit weight (g) for main treatments $(*)$ and subgroups of Pineapple mealybug wilt associated virus-free (PMWaV-free), or PMWaV-infected plants with or without mealybug exposure and with or without mealybug wilt of pineapple (MWP) symptoms during the plant crop

\begin{tabular}{|c|c|c|c|c|c|c|c|}
\hline \multirow[b]{2}{*}{ Virus status } & \multirow[b]{2}{*}{ MWPy } & \multicolumn{3}{|c|}{ Plant crop $^{x}$} & \multicolumn{3}{|c|}{ Ratoon crop $^{x}$} \\
\hline & & Fruit & Crown & $N^{\mathrm{z}}$ & Fruit & Crown & $N^{z}$ \\
\hline \multicolumn{8}{|l|}{ Mealybugs absent } \\
\hline *PMWaV-1- and PMWaV-2-free & Absent & $1,478 \mathrm{a}$ & $155 \mathrm{a}$ & 497 & $1,640 \mathrm{a}$ & $245 \mathrm{ab}$ & 683 \\
\hline PMWaV-2 only & Absent & $1,336 \mathrm{~b}$ & $158 \mathrm{a}$ & 23 & $1,572 \mathrm{ab}$ & $238 \mathrm{~b}$ & 35 \\
\hline *PMWaV-1 and dual infected & Absent & $1,358 \mathrm{~b}$ & $155 \mathrm{a}$ & 520 & $1,503 \mathrm{ab}$ & $257 \mathrm{a}$ & 566 \\
\hline PMWaV-1only & Absent & $1,389 \mathrm{~b}$ & $157 \mathrm{a}$ & 422 & $1,506 \mathrm{ab}$ & $261 \mathrm{a}$ & 465 \\
\hline Dual infected & Absent & $1,235 \mathrm{c}$ & $152 \mathrm{a}$ & 98 & $1,474 \mathrm{~b}$ & $236 \mathrm{~b}$ & 101 \\
\hline Total fruit & & & & 1,017 & 1,284 & & \\
\hline \multicolumn{8}{|l|}{ Mealybugs present } \\
\hline *PMWaV-1- and PMWaV-2-free & Absent & $1,480 \mathrm{a}$ & $153 \mathrm{a}$ & 500 & $1,651 \mathrm{a}$ & $238 \mathrm{~b}$ & 654 \\
\hline *PMWaV-1- and dual infected & Variable & $1,243 \mathrm{c}$ & $158 \mathrm{a}$ & 514 & $1,458 \mathrm{~b}$ & $250 \mathrm{ab}$ & 508 \\
\hline PMWaV-1 only & Absent & $1,399 \mathrm{~b}$ & $156 \mathrm{a}$ & 204 & $1,500 \mathrm{ab}$ & $253 \mathrm{ab}$ & 117 \\
\hline Dual infected & Present & $969 \mathrm{~d}$ & $159 \mathrm{a}$ & 310 & $1,448 \mathrm{~b}$ & $247 \mathrm{ab}$ & 391 \\
\hline Total fruit & & & & 1,014 & & & 1,162 \\
\hline
\end{tabular}

${ }_{\mathrm{x}}$ Average fruit weight $(\mathrm{g})$ without crown. Means within a column followed by different letters are different $(P<0.05)$ based on Fisher's LSD tests.

${ }^{y}$ MWP symptom status of plants during the plant crop. Present, typical MWP symptoms including severe tip dieback, reddening, and wilting of leaves present during the plant crop; absent, no MWP symptoms present; variable, includes plants with and without symptoms.

${ }^{\mathrm{z}}$ Total number of fruit in category. 
for analysis, and based groups on infection status with regard to the two different viruses and the status of mealybugs and MWP symptoms. The average fruit weight from plants that developed MWP symptoms at various intervals during the plant crop was 35\% lower than yields from PMWaV-free plants exposed to mealybugs, and $30 \%$ lower than yields from plants infected with PMWaV-1 or that had dual infections which did not develop MWP symptoms (Table 3). Plants infected with only PMWaV-1 produced fruit that weighed on the average $6 \%(P<0.05)$ less than fruit from PMWaV-free plants in the plant crop (Table 3). Mealybug presence or absence did not affect the average fruit weight of these plants (Table 3 ).

The average fruit weight from plant crop plants which developed symptoms 3, 6, 10, or 14 months after planting were all significantly different $(P<0.05)$ from each other; smaller fruits were produced by plants that developed MWP earliest in the crop cycle, regardless of recovery phenotype (Table 4). The mean fruit weight of the plants that developed wilt 14 months after planting was significantly $(P<0.05)$ larger than the mean fruit weight of all other treatments and subtreatments. The average fruit weight produced by plants that developed MWP were positively correlated $\left(R^{2}=0.978\right)$ with plant age at the time of symptom development (Fig. 2). Yields $(Y)$ based on the time of symptom expression $(X)$ fit the model

$$
Y=430.45 X^{0.54}
$$

Frequency distributions of plant crop fruit sizes showed a reduction in size 10 and 12 fruits in plots of PMWaV-1, or dually infected plants that were exposed to mealybugs (Fig. 3). This same treatment group had more fruit in the lower size categories (Under and 16) than all other groups analyzed. In the ratoon crop, there was more undersized fruit $(P<0.05)$ produced in the PMWaV-1-infected pineapple plots than in the PMWaV-1-free pineapple plots (Fig. 4).

Spatial analysis. Ordinary runs analyses down the rows of the mealybug-exposed, PMWaV-1 and dually infected plots

Table 4. Average pineapple fruit and crown weight $(\mathrm{g})$ produced by plants that developed mealybug wilt of pineapple symptoms $3,6,10$, or 14 months after planting

\begin{tabular}{lcl}
\hline Symptoms & $\begin{array}{c}\text { Fruit } \\
\text { weight }^{\mathbf{z}}\end{array}$ & $\begin{array}{c}\text { Crown } \\
\text { weight }^{\mathbf{z}}\end{array}$ \\
\hline 3 months & $665 \mathrm{~d}$ & $129 \mathrm{~b}$ \\
6 months & $948 \mathrm{c}$ & $143 \mathrm{ab}$ \\
10 months & $1,444 \mathrm{~b}$ & $152 \mathrm{a}$ \\
14 months & $1,589 \mathrm{a}$ & $150 \mathrm{a}$ \\
\hline
\end{tabular}

${ }^{\mathrm{z}}$ Based on four replicate plots of Pineapple mealybug wilt associated virus-1 (PMWaV-1) and PMWaV-2 infected plants exposed to mealybugs. Means followed by different letters are different $(P<0.05)$ based on Fisher's LSD and Waller-Duncan tests. showed that the patterns of MWP symptomatic plants initially fit a random distribution (underdispersion) within the plots at 3 months postplanting (Table 5). The random location of MWP symptomatic plants is consistent with the random planting of crowns unknowingly infected with PMWaV-2 in addition to PMWaV-1. Plants that developed MWP symptoms earliest were presumably infected with PMWaV-2 at the time the crowns were planted. At 6 months postplanting and at plant crop harvest, significant aggregation of MWP symptomatic plants along the rows was detected (Table 5). A modified runs analyses approach was used to analyze within-

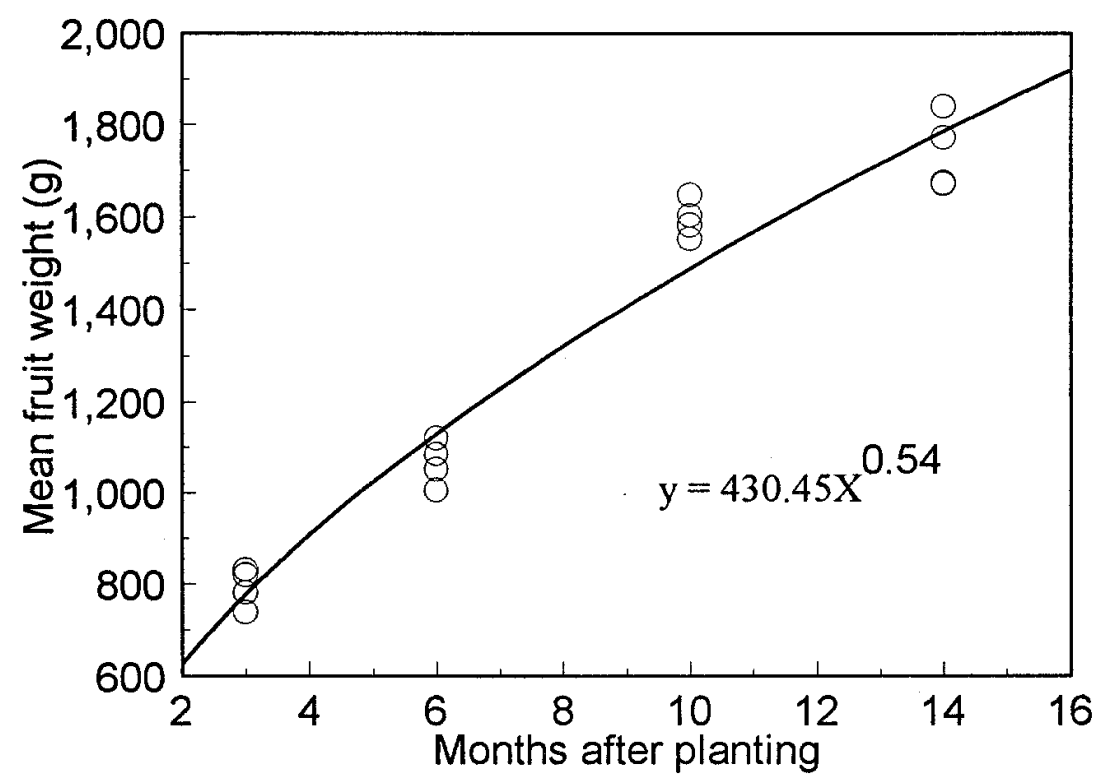

Fig. 2. The effects of plant age at the time of mealybug wilt of pineapple symptom induction on fruit yield.
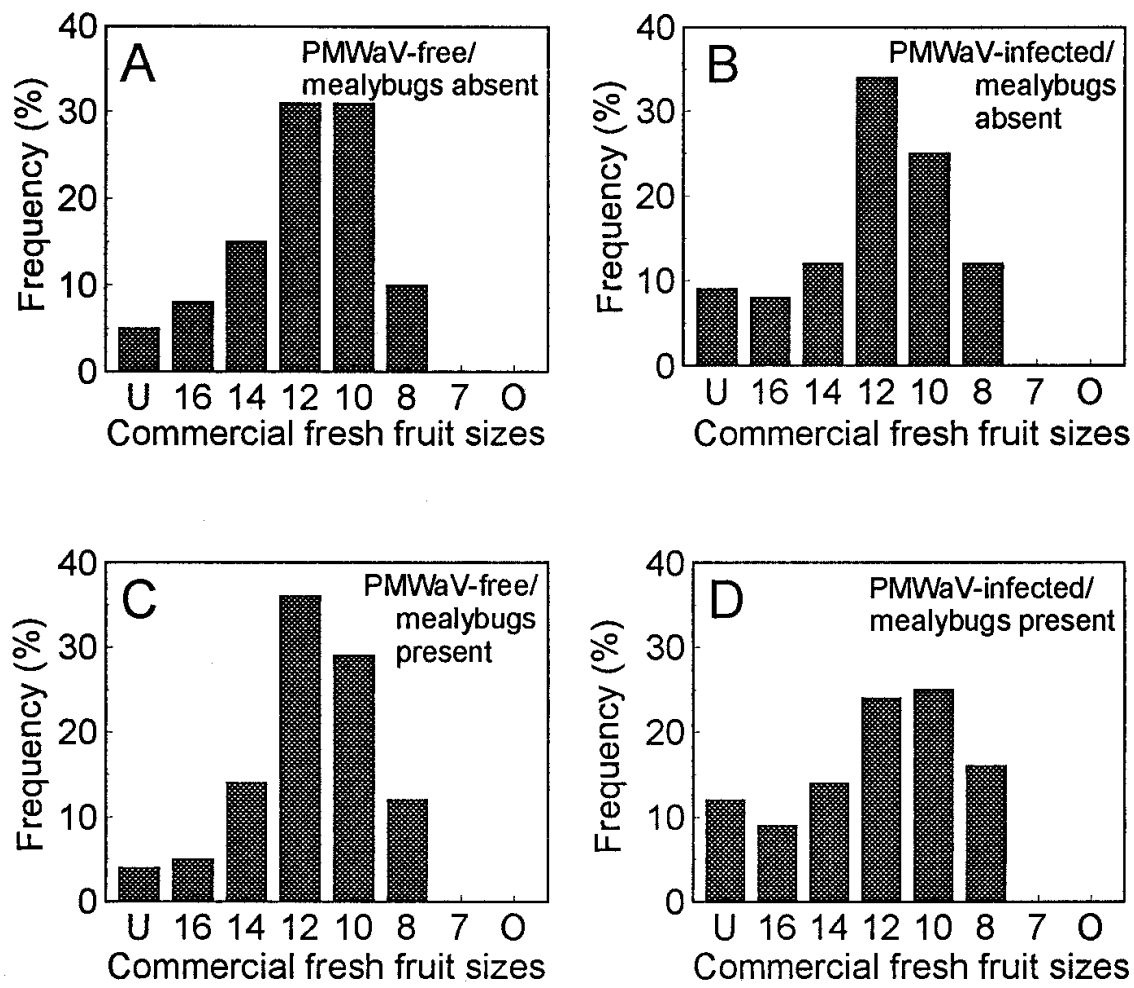

Fig. 3. Frequency distributions of pineapple fruit sizes produced in the plant crop from A, Pineapple mealybug wilt associated virus-free (PMWaV-free) plants maintained mealybug-free, B, PMWaVinfected plants maintained mealybug-free, C, PMWaV-free plants inoculated with mealybugs, and D, PMWaV-infected plants inoculated with mealybugs. Commercial fresh fruit size classes are: size 7 (2.6 to $2.9 \mathrm{~kg}$ ); size 8 (2.1 to $2.5 \mathrm{~kg}$ ); size 10 (1.7 to $2.0 \mathrm{~kg}$ ); size 12 (1.4 to $1.6 \mathrm{~kg}$ ); size 14 (1.2 to $1.3 \mathrm{~kg}$ ); size 16 (1.0 to $1.1 \mathrm{~kg}$ ); Under ( $<1.0 \mathrm{~kg}$ ); and Over (over $3.0 \mathrm{~kg}$ ). 
bed and between-bed patterns of MWP symptomatic plants in the four PMWaV-1infected plots inoculated with mealybugs (Table 6). The achieved probabilities $(P)$ for adjacent rows in the same bed (rows 1 and 2 and 3 and 4) were consistently lower than those of adjacent rows in different beds (rows 2 and 3 ) indicating aggregation (overdispersion). The achieved probabilities from paired rows in four plots were pooled into two groups and overall chisquare values calculated. Chi-square values for adjacent rows within a bed were 43.31, $16 \mathrm{df}(P<0.005)$ and 47.22, $16 \mathrm{df}(P<$ $0.005)$ at 6 months postplant and at plant crop harvest, respectively. This supports the hypothesis that significant aggregation of MWP symptomatic plants occurred in rows within the same bed. Chi-square analysis of pooled $P$-values for MWP

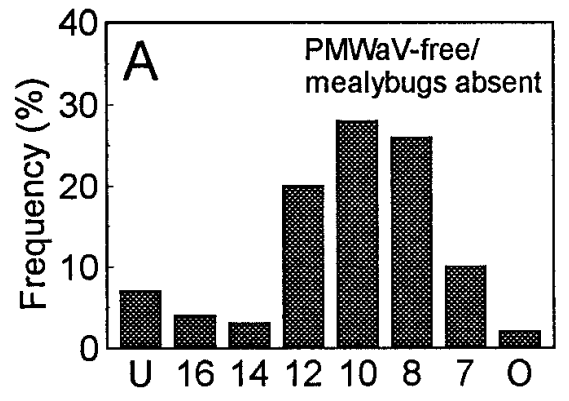

Commercial fresh fruit sizes

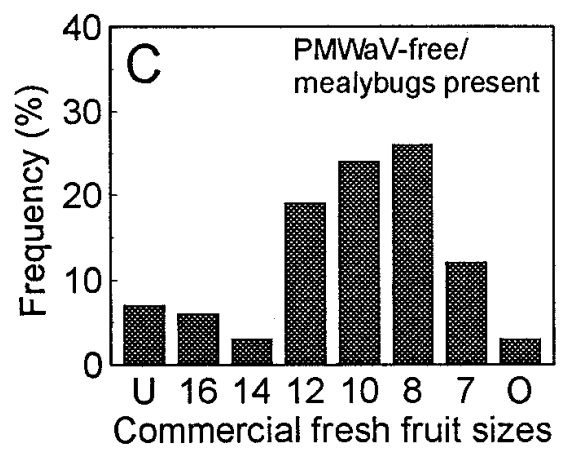

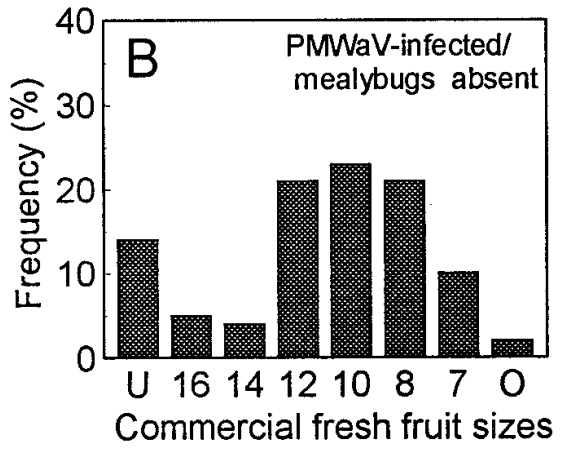



symptomatic plants in adjacent rows of different beds were $0.56,8 \mathrm{df}(P>0.999)$ and $1.85,8 \mathrm{df}(P>0.975)$ at 6 months postplanting and at plant crop harvest, respectively, showing that aggregation was not significant between adjacent rows in different beds. Rather, MWP symptomatic plants fit a random distribution when adjacent rows in two different beds were analyzed.

Ordinary runs analysis of PMWaV-2 incidence down the rows of the mealybug exposed, PMWaV-infected plots, showed that PMWaV-2-infected plants exhibited significant aggregation down rows at 6 months and at the time of harvest (Table 7). This suggests movement of mealybugs between adjacent plants and concomitant transmission of PMWaV-2. Modified ordinary runs analysis of patterns of PMWaV2-infected plants within and between beds in plots treated with mealybugs showed there was significant clustering present in adjacent rows within the same bed but not between adjacent rows in different beds (Table 8). Chi square analysis of the pooled $P$-values for adjacent rows within a bed (rows 1 and 2 and 3 and 4) were 39.15, $8 \mathrm{df},(P<0.005)$ and 43.49, $8 \mathrm{df},(P<$ $0.005)$ at 6 months after planting and at plant crop harvest, respectively. These values indicate an overall aggregation of PMWaV-2-infected plants in adjacent rows of the same bed similar to what was observed when MWP patterns were analyzed above. Chi-square values of the pooled $P$ values for adjacent rows in different beds (rows 2 and 3) were $0.39,8 \mathrm{df},(P>0.990)$ and 7.75, $8 \mathrm{df},(P>0.30)$ at 6 months after planting and at plant crop harvest, respectively. The pattern of PMWaV-2-infected plants was not aggregated between adjacent rows in different beds. Rather, PMWaV-2-infected plants, like MWP symptomatic plants, fit a random distribution when adjacent rows in two different beds were analyzed.

Fig. 4. Frequency distributions of pineapple fruit sizes produced in the ratoon crop from $\mathbf{A}$, Pineapple mealybug wilt associated virus-free (PMWaV-free) plants maintained mealybug-free, B, PMWaV-infected plants maintained mealybug-free, C, PMWaV-free plants inoculated with mealybugs, and D, PMWaV-infected plants inoculated with mealybugs. Commercial fresh fruit size classes are: size 7 ( 2.6 to $2.9 \mathrm{~kg}$ ); size 8 ( 2.1 to $2.5 \mathrm{~kg}$ ); size 10 (1.7 to $2.0 \mathrm{~kg}$ ); size 12 (1.4 to $1.6 \mathrm{~kg}$ ); size 14 (1.2 to $1.3 \mathrm{~kg}$ ); size 16 (1.0 to $1.1 \mathrm{~kg}$ ); Under (<1.0 kg); and Over (over $3.0 \mathrm{~kg}$ ).

Table 5. Ordinary runs analyses of the pattern of mealybug wilt of pineapple (MWP) symptomatic pineapple plants in four replicate plots 3 and 6 months after planting and at harvest

\begin{tabular}{|c|c|c|c|c|c|c|c|}
\hline Rep & Rows $^{v}$ & $\operatorname{Symp}(m)^{w}$ & Total $(N)^{x}$ & Obs runs $(U)^{y}$ & Exp runs $(E(U))^{z}$ & $Z$ & $P$ \\
\hline \multicolumn{8}{|c|}{3 months post plant } \\
\hline 1 & $1-4$ & 11 & 130 & 21 & 21 & 0.209 & 0.583 \\
\hline 2 & $1-4$ & 13 & 130 & 27 & 24 & 1.538 & 0.938 \\
\hline 3 & $1-4$ & 26 & 130 & 51 & 43 & 2.460 & 0.993 \\
\hline 4 & $1-4$ & 17 & 130 & 33 & 31 & 1.152 & 1.000 \\
\hline \multicolumn{8}{|c|}{6 months post plant } \\
\hline 1 & $1-4$ & 21 & 130 & 27 & 36 & -2.852 & 0.002 \\
\hline 2 & $1-4$ & 25 & 130 & 31 & 41 & -2.815 & 0.002 \\
\hline 3 & $1-4$ & 43 & 130 & 51 & 59 & -1.404 & 0.081 \\
\hline 4 & $1-4$ & 28 & 130 & 35 & 45 & -2.468 & 0.007 \\
\hline \multicolumn{8}{|c|}{ Plant crop harvest (18 months) } \\
\hline 1 & $1-4$ & 32 & 130 & 35 & 49 & -3.270 & 0.001 \\
\hline 2 & $1-4$ & 42 & 130 & 43 & 58 & -2.894 & 0.002 \\
\hline 3 & $1-4$ & 53 & 130 & 53 & 64 & -1.875 & 0.030 \\
\hline 4 & $1-4$ & 39 & 130 & 39 & 56 & -3.380 & 0.000 \\
\hline
\end{tabular}

$\mathrm{v}$ The four rows comprising each plot were treated as one contiguous row.

${ }^{w}$ The number of MWP symptomatic plants in the plot.

${ }^{x}$ Total number of plants in the plot.

y Number of observed runs.

${ }^{\mathrm{z}}$ Number of expected runs. 


\section{DISCUSSION}

This is the first report of a field trial to evaluate the yield impact of mealybugs and the two PMWaVs. MWP developed only in PMWaV-2-infected plants exposed to mealybugs. If either PMWaV-2 or mealybugs were absent, MWP did not develop. In the plant crop, the interaction effect detected between virus infection and mealybugs represented the development of MWP in plants that were exposed to mealybugs and infected with PMWaV-2. The lack of mealybug or interaction effects in the ratoon crop is consistent with the fact that mealybug applications were discontinued after the plant crop harvest, although low residual populations remained. Ratoon plants infected with PMWaV-2 did not show MWP symptoms regardless of the low residual mealybug population present on some plants. This suggests the existence of a mealybug population threshold or an increased tolerance by the plant towards either the virus or mealybug feeding during the ratoon cycle.

Mealybug populations are greatest in the presence of ants and often fail to thrive in their absence (12,21). Ants can protect mealybugs from their natural predators and parasitoids $(12,13)$, and also consume the honeydew produced by the mealybugs thus preventing fungal colonization. We controlled ant populations in the plant and ratoon crop to minimize possible confounding factors such as the development of large localized populations of mealybugs within or outside the treatment plots that could potentially bring PMWaV-2 in from neighboring plants. In doing this, we may have slowed the rate of MWP development and PMWaV-2 spread, or altered the patterns that may have occurred if ants had been allowed to tend the mealybugs in the plots. Control of MWP by the commercial pineapple plantations in Hawaii is based on controlling ants through the use of the ant bait, Amdro, and by application of diazinon to control mealybugs and ants $(10,26)$. The use of virus-free planting material, a more environmentally sound alternative, would also have the benefit of increased yields $(27,30)$. Such PMWaVfree material could be derived from virusfree parent plants identified by PMWaV- specific MAbs in TBIA or produced through meristem tissue culture that eliminates PMWaV from infected crowns (32).

The development of MWP during the first 3 months of the plant crop resulted in a $55 \%$ reduction in average fruit weight compared to fruits from PMWaV-free plants. However, the appearance of MWP late in the plant crop cycle did not reduce fruit weight. Plants that developed MWP 14 months after planting produced fruits that averaged $7 \%$ heavier than fruit from PMWaV-free plants. This is suggestive of a growth response to the added stress of MWP during flowering. The dependence of yield on time of MWP symptom appearance suggests that prevention of MWP during the early stages of the crop is more critical for maximizing yield. In situations where resources are limited, efforts should be directed at the prevention of MWP early in the crop cycle through the use of mealybug and ant control practices and roguing of symptomatic plants. Ideally, PMWaV-2infected plants should also be eliminated.

The fruit sizes desired by commercial pineapple growers depends on the target

Table 6. Modified ${ }^{t}$ ordinary runs analysis of the patterns of mealybug wilt of pineapple (MWP) symptomatic plants in adjacent rows within the same bed ${ }^{u}$ and adjacent rows in different beds ${ }^{\mathrm{v}}$ at 14 months after planting

\begin{tabular}{|c|c|c|c|c|c|c|c|}
\hline Rep & Rows & $\operatorname{Symp}(m)^{w}$ & Total $(N)^{x}$ & Obs. runs $(U)^{\mathbf{y}}$ & Exp. runs $(E(U))^{\mathrm{z}}$ & $Z$ & $P$ \\
\hline 1 & 1 and 2 & 13 & 65 & 15 & 22 & -2.484 & 0.007 \\
\hline 1 & 2 and 3 & 10 & 65 & 21 & 18 & 1.743 & 0.959 \\
\hline 1 & 3 and 4 & 8 & 65 & 11 & 15 & -2.089 & 0.018 \\
\hline 2 & 1 and 2 & 14 & 65 & 21 & 22 & -0.548 & 0.291 \\
\hline 2 & 2 and 3 & 12 & 65 & 19 & 18 & -0.449 & 0.326 \\
\hline 2 & 3 and 4 & 11 & 65 & 13 & 15 & -2.601 & 0.005 \\
\hline 3 & 1 and 2 & 19 & 65 & 29 & 28 & 0.487 & 0.688 \\
\hline 3 & 2 and 3 & 20 & 65 & 33 & 29 & 1.415 & 0.922 \\
\hline 3 & 3 and 4 & 24 & 65 & 29 & 31 & -0.477 & 0.316 \\
\hline 4 & 1 and 2 & 9 & 65 & 17 & 17 & 0.529 & 0.702 \\
\hline 4 & 2 and 3 & 12 & 65 & 23 & 21 & 1.230 & 0.891 \\
\hline 4 & 3 and 4 & 19 & 65 & 21 & 28 & -1.938 & 0.026 \\
\hline
\end{tabular}

${ }^{t}$ See MATERIALS AND METHODS section.

u Rows 1 and 2 and rows 3 and 4.

v Rows 2 and 3.

${ }^{w}$ The number of MWP symptomatic plants in the plot.

$\mathrm{x}$ Total number of plants in the plot.

y Number of observed runs.

${ }^{\mathrm{z}}$ Number of expected runs.

Table 7. Ordinary runs analysis of the pattern of Pineapple mealybug wilt associated virus-2-(PMWaV-2) infected plants 6 months after planting and at plant crop harvest in four replicate plots

\begin{tabular}{|c|c|c|c|c|c|c|c|}
\hline Rep & Rows $^{v}$ & Infected $(m)^{\mathrm{w}}$ & Total $(N)^{x}$ & Obs runs $(U)^{y}$ & $\operatorname{Exp} \operatorname{runs}(E(U))^{\mathbf{z}}$ & $Z$ & $P$ \\
\hline \multicolumn{8}{|c|}{6 months post plant } \\
\hline 1 & $1-4$ & 40 & 130 & 31 & 56 & -5.150 & $<0.001$ \\
\hline 2 & $1-4$ & 48 & 130 & 37 & 62 & -4.549 & $<0.001$ \\
\hline 3 & $1-4$ & 62 & 130 & 43 & 66 & -3.946 & $<0.001$ \\
\hline 4 & $1-4$ & 40 & 130 & 35 & 56 & -4.322 & $<0.001$ \\
\hline \multicolumn{8}{|c|}{ Plant crop harvest } \\
\hline 1 & $1-4$ & 73 & 130 & 33 & 65 & -5.636 & $<0.001$ \\
\hline 2 & $1-4$ & 71 & 130 & 33 & 65 & -5.674 & $<0.001$ \\
\hline 3 & $1-4$ & 97 & 130 & 33 & 50 & -3.902 & $<0.001$ \\
\hline 4 & $1-4$ & 86 & 130 & 29 & 59 & -5.848 & $<0.001$ \\
\hline
\end{tabular}

$\mathrm{v}$ The four rows comprising each plot were treated as one contiguous row.

w The number of PMWaV-2-infected plants in the plot.

$x$ Total number of plants in the plot.

y Number of observed runs.

${ }^{\mathrm{z}}$ Number of expected runs. 
market. In general, a distribution that has minimal fruit in the Over and Under categories, and the majority of the fruit in the 8,10 , and 12 size classes is most desirable. Visual inspection of the frequency distributions, although somewhat subjective, shows that the most preferable size frequency distributions in the plant and ratoon crops were from the PMWaV-free groups, regardless of mealybug exposure. Similar size frequency trends were observed previously in PMWaV-1-free and infected pineapple (30) and are evidence that PMWaVfree plants are more desirable than PMWaV-infected plants with regards to desirable fruit size production.

Identification of disease patterns and spread in the field is paramount in epidemiological investigations. A random pattern of infected or symptomatic plants suggests that, at the time of observation, the pathogen is not spreading from plant to plant or that there is a delay between infection and symptom expression. Alternatively, aggregations of infected or symptomatic plants suggest pathogen spread from plant to plant (24). The significant overdispersion of MWP symptomatic plants and PMWaV-2 incidence observed in the plot rows indicated that mealybugs were acquiring $\mathrm{PMWaV}-2$ from infected plants initially in the plots, moving to a neighboring plant and subsequently transmitting the virus. The chi-square values achieved from pooled probabilities showed that MWP and PMWaV-2 tends to be clustered within a bed. Overdispersion was previously observed when static frequency distributions of diseased plants per sampling unit were fitted to statistical probability distributions (19). We observed exceptions to overdispersion in plots 3 months after mealybug applications began. Similar underdispersion was observed by Hughes and Samita (19) in some fields. This could be explained by the initially random dispersion of PMWaV-2-infected plants prior to mea- lybug infestation. When these randomly dispersed PMWaV-2-infected plants become infested with mealybugs they develop MWP. As mealybug populations become established on PMWaV-2-infected plants, acquisition of the virus occurs and is subsequently transmitted to neighboring plants when mealybugs move to them. Mealybug movement is constrained by the female's lack of wings. Adult males are alate but lack developed mouthparts and do not feed. Although crawlers are phototaxic and are readily dispersed by wind to distant plants, they are susceptible to dessication. Thus, plants immediately adjacent to mealybug-infested, PMWaV-2-infected plants may have higher probabilities of becoming mealybug-infested and subsequently infected by PMWaV-2. Roguing of only MWP-symptomatic plants may be inadequate to control virus spread. Removal of neighboring plants may also be needed to minimize the chances of MWP symptom development and the impact of virus infection on yields. The number of plants removed would be dependent on many factors including the size of the mealybug population, the presence or absence of ants, the environmental conditions, and plant or row spacing.

Management of MWP is paramount in Hawaii. High costs of labor and shipping of fresh fruit make cost-effective MWP control essential. Identification and removal of virus-infected plants may be a strategy to control MWP. Unfortunately, this strategy is laborious, somewhat subjective, and requires sending personnel into fields to remove symptomatic plants. Maximizing the spacing of crop rows may impact the spread of PMWaVs and MWP in the presence of mealybugs. The observation that aggregation of MWP and PMWaV-2 is significant in rows within a bed, rather than between beds, indicates proximity to an infected and infested plant is an important factor in the spread of
PMWaV-2 and the concomitant development of MWP. Beds of pineapple are typically raised and covered with black plastic mulch. In Hawaii, two different mulching schemes are used. One uses a single bed that results in a raised bed of two rows covered with plastic mulch. Each bed is separated by exposed soil that provides an aisle for harvester access. The spacing between the beds is greater than that between the rows within a bed. A second type of mulching scheme is a double bed consisting of four rows within a bed and depressions (aisles) on each side between the beds. The spacing between rows is similar in both mulching schemes. However, the double beds put more plants in closer proximity to one another than does the single bed. In our study, we used a single bed scheme. The single bed may potentially provide better control of the spread of MWP in the presence of low mealybug or ant populations because of the reduced number of plants in close proximity to one another. Alternatively, the double bed may be conducive to a more rapid spread of MWP or PMWaVs because the leaves and roots of a higher number of plants are growing in close proximity. Further studies are underway to evaluate these scenarios.

\section{ACKNOWLEDGMENTS}

This research was funded, in part, by grants from the State of Hawaii Governor's Agricultural Coordinating Committee contract No. 87-12, the Hawaii Department of Agriculture contract No. 43754, and the specific Cooperative Grant agreement 58-5320-5-604 between the USDA-ARS and the University of Hawaii at Manoa. We thank W. Borth, M. Melzer, and Eden Perez for providing comments and suggestions regarding this manuscript. This is Journal Series No. 4600 of the College of Tropical Agriculture and Human Resources.

\section{LITERATURE CITED}

1. Borroto, E. G., Cintra, M., Gonzalez. J., Borroto, C., and Oramas, P. 1998. First report of closterovirus-like particle associated with pineapple plants (Ananas comosus cv. Smooth

Table 8. Modified ${ }^{t}$ ordinary runs analysis of the patterns of Pineapple mealybug wilt associated virus-2- (PMWaV-2) infected plants in adjacent rows within the same bed ${ }^{\mathrm{u}}$ and adjacent rows in different beds ${ }^{\mathrm{v}} 6$ months after planting

\begin{tabular}{|c|c|c|c|c|c|c|c|}
\hline Rep & Rows & Infected $(m)^{\mathrm{w}}$ & Total $(N)^{\mathrm{x}}$ & Obs. runs $(U)^{y}$ & Exp. runs $(E(U))^{z}$ & $Z$ & $P$ \\
\hline 1 & 1 and 2 & 22 & 65 & 19 & 30 & -2.967 & 0.002 \\
\hline 1 & 2 and 3 & 20 & 65 & 33 & 29 & 1.415 & 0.922 \\
\hline 1 & 3 and 4 & 18 & 65 & 24 & 27 & -0.793 & 0.215 \\
\hline 2 & 1 and 2 & 30 & 65 & 26 & 33 & -1.712 & 0.044 \\
\hline 2 & 2 and 3 & 22 & 65 & 35 & 30 & 1.508 & 0.935 \\
\hline 2 & 3 and 4 & 18 & 65 & 23 & 27 & -1.107 & 0.134 \\
\hline 3 & 1 and 2 & 28 & 65 & 27 & 33 & -1.371 & 0.085 \\
\hline 3 & 2 and 3 & 28 & 65 & 43 & 33 & 2.709 & 0.997 \\
\hline 3 & 3 and 4 & 34 & 65 & 31 & 33 & -.0484 & 0.316 \\
\hline 4 & 1 and 2 & 14 & 65 & 19 & 23 & -1.293 & 0.099 \\
\hline 4 & 2 and 3 & 18 & 65 & 32 & 27 & 1.714 & 0.956 \\
\hline 4 & 3 and 4 & 26 & 65 & 33 & 32 & 0.339 & 0.633 \\
\hline
\end{tabular}

${ }^{\mathrm{t}}$ See MATERIALS AND METHODS section.

u Rows 1 and 2 and rows 3 and 4 .

$\checkmark$ Rows 2 and 3 .

${ }^{\mathrm{w}}$ The number of PMWaV-2-infected plants in the plot.

$\mathrm{x}$ Total number of plants in the plot.

y Number of observed runs.

${ }^{\mathrm{z}}$ Number of expected runs. 
Cayenne) affected with pineapple mealybug wilt in Cuba. Plant Dis. 82:263.

2. Campbell, C. L., and Madden, L. V. 1990. Spatial aspects of plant disease epidemics II: Analysis of spatial pattern. Pages 289-328 in Introduction to Plant Disease Epidemiology. John Wiley \& Sons, New York.

3. Carter, W. 1933. The pineapple mealy bug, Pseudococcus brevipes, and wilt of pineapples. Phytopathology 23:207-242.

4. Carter, W. 1934. Mealybug wilt and green spot in Jamaica and Central America. Phytopathology 24:424-426.

5. Carter, W. 1942. Geographic distribution of mealybug wilt with some other insect pests of pineapple. J. Econ. Entomol. 35:10-15.

6. Carter, W. 1945. Some etiological aspects of mealybug wilt. Phytopathology 35:305-315.

7. Carter, W. 1951. The feeding sequence of Pseudococcus brevipes (Ckl.) in relation to mealybug wilt of pineapples in Hawaii. Phytopathology 41:769-780.

8. Carter, W. 1963. Mealybug wilt of pineapple; a reappraisal. Ann. NY Acad. Sci.105:741764.

9. Devore, J., and Peck, R. 1986. Statistics. The Exploration and Analysis of Data. West Publishing Co., St. Paul, MN.

10. German, T. L., Ullman, D. E., and Gunasinghe, U. B. 1992. Mealybug Wilt of Pineapple. Adv. Dis. Vector Res. 9:241-259.

11. Gibbons, J. D. 1976. Nonparametric Methods for Quantitative Analysis. Holt, Rinehart and Winston, New York.

12. González-Hernández, H., Johnson, M. W., and Reimer, N. J. 1999. Impact of Pheidole megacephala (F.) (Hymenoptera: Formicidae) on the biological control of Dysmicoccus brevipes (Cockerell) (Homoptera: Pseudococcidae). Biol. Control 15:145-152.

13. González-Hernández, H., Reimer, N. J., and Johnson, M. W. 1999. Survey of the natural enemies of Dysmicoccus mealybugs on pineapple in Hawaii. Bio Control 44:47-58.

14. Gunasinghe, U. B., and German, T. L. 1989.
Purification and partial characterization of a virus from pineapple. Phytopathology 79:1337-1341.

15. Hu, J. S., Gonsalves, A., Sether, D., and Ullman, D. E. 1993. Detection of pineapple closterovirus, a possible cause of mealybug wilt of pineapple. Acta Hortic. 334: 411-416.

16. Hu, J. S., and Sether, D. M. 1999. Etiology of mealybug wilt of pineapple. Page 321 in: Abstracts of the Xth Int. Congr. Virol., Sydney, Australia.

17. Hu, J. S., Sether, D. M., Liu, X. P., Wang, M., Zee. F., and Ullman, D. 1997. Use of a tissue blotting immunoassay to examine the distribution of pineapple mealybug wilt-associated virus in Hawaii. Plant Dis. 81:1150-1154.

18. Hu, J. S., Sether, D. M., and Ullman, D. E. 1996. Detection of pineapple mealybug wiltassociated virus in pineapple plants and mealybugs using monoclonal antibodies. Plant Pathol. 45:829-836.

19. Hughes, G., and Samita, S. 1998. Analysis of patterns of pineapple mealybug wilt disease in Sri Lanka. Plant Dis. 82:885-890.

20. Illingworth, J. F. 1931. Preliminary report on evidence that mealybugs are an important factor in pineapple wilt. J. Econ. Entomol. 24:877-889.

21. Jahn, G. C. 1992. The ecological significance of the big-headed ant in mealybug wilt disease of pineapple. $\mathrm{Ph}$. D. thesis. University of Hawaii, Honolulu.

22. Karasev, A. V. 2000. Genetic diversity and evolution of closteroviruses. Annu. Rev. Phytopathol. 38:293-324

23. Krauss, B. 1948. Anatomy of the vegetative organs of the pineapple, Ananas comosus (L.) Merr. Bot. Rev.110:159-217.

24. Madden, L. V., Louie, R., Abt, J. J., and Knoke, J. K. 1982. Evaluation of tests for randomness of infected plants. Phytopathology 72:195-198.

25. Melzer, M. J., Karasev, A. V., Sether, D. M., and $\mathrm{Hu}$, J. S. 2001. Nucleotide sequence, genome organization, and phylogenetic analysis of pineapple mealybug wilt-associated virus2. J. Gen. Virol.82:1-7.

26. Rohrbach, K. G., Beardsley, J. W., German, T. L., and Reimer, N. J., and Sanford, W. G. 1988. Mealybug wilt, mealybugs, and ants on pineapple. Plant Dis. 72:558-565

27. Sether, D. M., and Hu, J. S. 1998. Corollary analyses of the presence of pineapple mealybug wilt associated virus and the expression of mealybug wilt symptoms, growth reduction, and/or precocious flowering of pineapple. (Abstr) Phytopathology 88:S80.

28. Sether, D. M., and Hu J. S. 1999. Mealybugs and pineapple mealybug wilt associated virus are both necessary for mealybug wilt. (Abstr) Phytopathology 89:S70

29. Sether, D. M., and Hu, J. S. 2000. A closterovirus and mealybug exposure are both necessary components for mealybug wilt of pineapple symptom induction. (Abstr) Phytopathology 90:S71.

30. Sether, D. M., and Hu, J. S. 2001. The impact of pineapple mealybug wilt-associated virus and reduced irrigation on pineapple yield. Australas. Plant Pathol. 30:31-36.

31. Sether, D. M., and Hu, J. S. Closterovirus infection and mealybug exposure are both necessary factors for the development of mealybug wilt of pineapple disease. Phytopathology. (In press.)

32. Sether, D. M., Okamura, C., Kislan, M. M Karasev, A., Busto, J. L., and Hu, J. S. 2001. Detection, differentiation, and elimination of pineapple mealybug wilt associated virus in pineapple. Plant Dis. 85:856-864

33. Sether, D. M., Ullman, D. E., and Hu, J. S 1998. Transmission of pineapple mealybug wilt-associated virus by two species of mealybug (Dysmicoccus spp.). Phytopathology 88:1224-1230.

34. Wakman, W., Teakle, D. S., Thomas, J. E., and Dietzgen, R. G. 1995. Presence of a clostero-like virus and a bacilliform virus in pineapple plants in Australia. Aust. J. Agric. Res 46:947-958. 